\title{
Purification and Characterization of an Extracellular and a Cellular $\alpha$-Glucosidase from Bacillus licheniformis
}

\author{
By M. THIRUNAVUKKARASU AND FERGUS G. PRIEST* \\ Department of Brewing and Biological Sciences, Heriot-Watt University, Chambers Street, \\ Edinburgh EH1 $1 H X, U K$
}

(Received 28 February 1984 ; revised 6 June 1984)

$\alpha$-Glucosidase has been purified from culture fluid and from lysed cells of Bacillus licheniformis NCIB 6346. The enzymes from these two sources were virtually identical in molecular weight as judged by SDS-PAGE (63000) and catalytic properties. The enzymes were unstable at high temperature and lost all activity after incubation at $60^{\circ} \mathrm{C}$ for $10 \mathrm{~min}$. Of the substrates examined, isomaltose gave maximal activity, followed by maltotriose, $p$-nitrophenyl $\alpha$-D-glucopyranoside, sucrose and maltose. With isomaltose or maltotriose as substrate, transglucosylation activity was evident.

\section{INTRODUCTION}

The final stage of starch metabolism in many micro-organisms is effected by $\alpha$-glucosidase. This enzyme ( $\alpha$-D-glucosidase, EC 3.2.1.20) hydrolyses the $(1 \rightarrow 4)-\alpha$ - and/or the $(1 \rightarrow 6)-\alpha-$ linkages in the oligosaccharides remaining after degradation of starch by amylases. $\alpha$-Glucosidase is distributed widely amongst micro-organisms and has been purified and characterized from bacteria, yeasts and moulds (reviewed by Kelly \& Fogarty, 1983). The enzymes differ in their substrate specificities. Of those from Bacillus strains, the $\alpha$-glucosidases from 'B. amylolyticus' (Kelly et al., 1980), B. brevis (McWethy \& Hartman, 1979), B. cereus (Suzuki \& Tanaka, 1981), B. megaterium (Kelly \& Fogarty, 1983) and B. subtilis P-11 (Wang \& Hartman, 1976) have been termed 'maltases' since they have a high activity towards maltose and little, if any activity towards $p$-nitrophenyl $\alpha$-D-glucopyranoside (PNPG). The other group of $\alpha$-glucosidases is more sparsely represented and includes those enzymes that hydrolyse PNPG more rapidly than maltose. The enzymes from ' $B$. thermoglucosidius' (Suzuki et al., 1979) and ' $B$. amyloliquefaciens' (Urlaub \& Wöber, 1978) are in this category but differ in that the former displays high activity towards isomaltose and has been designated as an oligo- $(1 \rightarrow 6)-\alpha-D-$ glucosidase (EC 3.2.1.10) while the latter displays maximal activity towards sucrose.

An interesting feature of these enzymes is their cellular location. In ' $B$. amylolyticus' (Kelly et al., 1980), B. brevis (McWethy \& Hartman, 1979) and B. subtilis P-11 (Wang \& Hartman, 1976) the enzyme is extracellular. In B. cereus (Suzuki \& Tanaka, 1981) and B. megaterium (Kelly \& Fogarty, 1983) the enzyme is cytoplasmic and in ' $B$. thermoglucosidius' it has been shown to accumulate in the cytoplasm during exponential growth before subsequent release into the culture fluid, possibly as a result of cell lysis (Suzuki et al., 1976a, b). In 'B. amyloliquefaciens' the enzyme is membrane bound (Urlaub \& Wöber, 1978). The distribution of $\alpha$-glucosidase in $B$. licheniformis NCIB 6346 appears to vary. In young cells it is largely cytoplasmic but, as the culture enters late exponential phase, the enzyme can be released by protoplast formation. Finally, in early stationary phase cultures, it can be detected in the culture fluid (Thirunavukkarasu \& Priest, 1983). In this paper, we report the purification and characterization of the intracellular and extracellular $\alpha$-glucosidases of $B$. licheniformis NCIB 6346. The two enzymes were essentially identical.

Abbreviation: PNPG, p-nitrophenyl $\alpha$-D-glucopyranoside. 


\section{METHODS}

Organism and growth conditions. Bacillus licheniformis NCIB 6346 was obtained from the National Collection of Industrial Bacteria, Aberdeen, UK. It was grown in a medium that had been optimized for the yield of intracellular and extracellular $\alpha$-glucosidase and contained $\left(\mathrm{g} \mathrm{l}^{-1}\right): \mathrm{KH}_{2} \mathrm{PO}_{4}, 14 ; \mathrm{K}_{2} \mathrm{HPO}_{4}$, 6; trisodium citrate, 1 ; $\mathrm{MgSO}_{4} .7 \mathrm{H}_{2} \mathrm{O}, 0.2$; bacteriological peptone (Oxoid), 45 and waxy-maize starch, 15 . The medium (3.5 I), in a 5 litre fermenter, was autoclaved at $121^{\circ} \mathrm{C}$ for $30 \mathrm{~min}$. An inoculum was prepared by shaking cells in $100 \mathrm{ml}$ nutrient broth (Oxoid no. 1) at $37^{\circ} \mathrm{C}$ for $16 \mathrm{~h}$ and $10 \mathrm{ml}$ was inoculated into $50 \mathrm{ml}$ of the optimized medium. After shaking for $7 \mathrm{~h}$ at $37^{\circ} \mathrm{C}, 25 \mathrm{ml}$ of the cell suspension was transferred to the fermenter and incubated at $37^{\circ} \mathrm{C}$ for $16 \mathrm{~h}$ with constant stirring. Aeration was at 5 litres $\mathrm{min}^{-1}$ and foaming was controlled by the addition of silicone antifoam. The cells were harvested by centrifugation $\left(5000 \mathrm{~g}, 20 \mathrm{~min}, 4^{\circ} \mathrm{C}\right)$ and used for purification of the intracellular enzyme; the supernatant was used for the purification of the extracellular enzyme.

Analytical procedures. $\alpha$-Glucosidase activity was assayed by measuring the $p$-nitrophenol released from PNPG (Sigma). The reaction mixture contained phosphate buffer $(2 \mathrm{ml}, 0.1 \mathrm{M}, \mathrm{pH} \mathrm{6.5})$, PNPG (250 $\mu \mathrm{g})$ and enzyme solution $(0.1 \mathrm{ml})$. After incubation at $37^{\circ} \mathrm{C}$ for $20 \mathrm{~min}, 1 \mathrm{ml} \mathrm{Na}{ }_{2} \mathrm{CO}_{3}(5 \mathrm{M})$ was added and the absorbance measured at $420 \mathrm{~nm}$. One unit of activity is the amount of enzyme that gives an increase of one absorbance unit under these conditions. Glucose was assayed using glucose oxidase $\left(300 \mu \mathrm{g} \mathrm{ml}^{-1}\right.$, Boehringer) and horseradish peroxidase (30 $\mu \mathrm{g} \mathrm{ml}^{-1}$, Boehringer) dissolved in Tris/phosphate buffer $(0.1 \mathrm{M}, \mathrm{pH} \mathrm{7.0)}$ with 2,2'-azino-di-(3-ethylbenzthiazoline sulphonic acid) $\left(750 \mu \mathrm{g} \mathrm{ml}^{-1}\right.$, Sigma). This solution $(1 \mathrm{ml})$ was incubated with $1 \mathrm{ml}$ enzyme digest (see Table 2) for $20 \mathrm{~min}$ at $20^{\circ} \mathrm{C}, \mathrm{HCl}(1 \mathrm{ml}, 1 \mathrm{M})$ was added and the absorbance at $420 \mathrm{~nm}$ was related to glucose concentration with a standard curve. Protein was assayed using the Lowry procedure. TLC was done on silica gel G plates (Merck) developed in acetic acid/chloroform/water $(35: 30: 5$, by vol.). After $6 \mathrm{~h}$ the plates were dried and sprayed with phenol/sulphuric acid reagent (phenol, $3 \mathrm{~g} ; \mathrm{H}_{2} \mathrm{SO}_{4}, 5 \mathrm{ml}$; ethanol, $95 \mathrm{ml}$ ) and heated at $110^{\circ} \mathrm{C}$ for $10 \mathrm{~min}$. Sugars appeared as brown spots. PAGE was done in tubes containing $7.5 \%(\mathrm{w} / \mathrm{v})$ polyacrylamide at $5 \mathrm{~mA}$ per tube for $2 \mathrm{~h}$. SDS-PAGE was done according to Weber \& Osborn (1969) using 10\% (w/v) polyacrylamide gels. The gels were stained with Coomassie blue.

Purification of extracellular enzyme. All steps were done at $4{ }^{\circ} \mathrm{C} .\left(\mathrm{NH}_{4}\right)_{2} \mathrm{SO}_{4}\left(313 \mathrm{~g} \mathrm{l}^{-1}\right)$ was added slowly to the culture fluid. The solution was stirred for $6 \mathrm{~h}$, then centrifuged $(12000 \mathrm{~g}, 30 \mathrm{~min})$ and the precipitate discarded. More $\left(\mathrm{NH}_{4}\right)_{2} \mathrm{SO}_{4}\left(214 \mathrm{~g} \mathrm{l}^{-1}\right)$ was added to the supernatant and stirred overnight. The precipitate was recovered by centrifugation, dissolved in $25 \mathrm{~mm}$-phosphate buffer ( $\mathrm{pH} \mathrm{6.5)} \mathrm{and} \mathrm{dialysed} \mathrm{overnight} \mathrm{against} \mathrm{the} \mathrm{same} \mathrm{buffer.} \mathrm{The}$ enzyme solution was loaded onto a DEAE-cellulose (Whatman DE52) column $(2.5 \mathrm{~cm} \times 30 \mathrm{~cm})$ that had been equilibrated with $25 \mathrm{~mm}$-phosphate buffer ( $\mathrm{pH} 6.5$ ). It was eluted using a linear gradient of $0-0.5 \mathrm{M}-\mathrm{NaCl}$ at $20 \mathrm{ml} \mathrm{h}^{-1}$ and 120 fractions ( $5 \mathrm{ml}$ each) were collected. $\alpha$-Glucosidase was recovered in a single peak of activity in fractions 82 to 98 . These were pooled, $\left(\mathrm{NH}_{4}\right)_{2} \mathrm{SO}_{4}\left(561 \mathrm{~g} \mathrm{l}^{-1}\right)$ was added, and the solution was stirred for $6 \mathrm{~h}$ and centrifuged as before. The precipitate was dissolved in $25 \mathrm{~mm}$-phosphate buffer (pH 6.5) and loaded onto a Sepha$\operatorname{dex}$ G-200 $(2.5 \mathrm{~cm} \times 75 \mathrm{~cm})$ column. Fractions $(5 \mathrm{ml})$ were eluted at a flow rate of $10 \mathrm{ml} \mathrm{h}^{-1}$ and the $\alpha$-glucosidase activity was recovered as a single peak of activity in fractions 30 to 52 . Analysis of this material by PAGE revealed four bands stained by Coomassie blue. The enzyme was therefore concentrated by $\left(\mathrm{NH}_{4}\right)_{2} \mathrm{SO}_{4}$ precipitation $\left(561 \mathrm{~g}^{-1}\right)$; the precipitate was dissolved in $25 \mathrm{mM}$-phosphate buffer ( $\mathrm{pH} \mathrm{6.5)} \mathrm{and} \mathrm{loaded} \mathrm{onto} \mathrm{an} \mathrm{Ultragel} \mathrm{AcA} 44$ (LKB) column $(3.5 \mathrm{~cm} \times 42 \mathrm{~cm})$. Fractions $(3 \mathrm{ml})$ were eluted using the same buffer $\left(20 \mathrm{ml} \mathrm{h}^{-1}\right.$ flow rate) and the enzyme activity was recovered in fractions 30 to 40 . Although this provided greater than 1000 -fold purification (Table 1) the material still revealed two protein bands after PAGE. The pooled fractions from the AcA 44 column were concentrated by ultrafiltration and $400 \mu \mathrm{l}$ was loaded onto preparative polyacrylamide gels $(1.2 \mathrm{~cm} \times 10 \mathrm{~cm})$. After electrophoresis for $2 \mathrm{~h}$ at $4{ }^{\circ} \mathrm{C}$ and $5 \mathrm{~mA}$ per tube, the gels were incubated at $37^{\circ} \mathrm{C}$ for $10 \mathrm{~min}$ in $5 \mathrm{~mm}$ phosphate buffer ( $\mathrm{pH} 6.5)$ containing PNPG $\left(1 \mathrm{mg} \mathrm{ml}^{-1}\right)$. The region of the gel containing $\alpha$-glucosidase, which was revealed as a yellow band, was removed, crushed and ground in water in a pre-chilled mortar. The gel solution

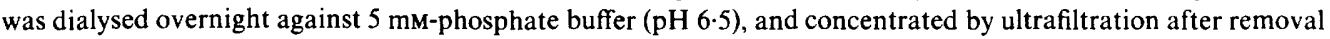
of pieces of gel by centrifugation. The purified enzyme migrated as a single band after SDS-PAGE. It was stored at $-20^{\circ} \mathrm{C}$ and was used for all assays.

Purification of the intracellular enzyme. Cells (5-10 g wet weight) were suspended in $45 \mathrm{ml}$ phosphate buffer $\left(0.1 \mathrm{M}, \mathrm{pH} \mathrm{6.5)}\right.$ and lysozyme solution was added to a final concentration of $100 \mu \mathrm{g} \mathrm{ml}^{-1}$. After incubation at $37^{\circ} \mathrm{C}$ for $15 \mathrm{~min}$, DNAase (Sigma, $50 \mu \mathrm{g} \mathrm{ml}^{-1}$ ) was added and incubation continued for a further $15 \mathrm{~min}$. Cell debris was removed by centrifugation $(12000 \mathrm{~g}, 30 \mathrm{~min})$, streptomycin sulphate was added to the supernatant to $20 \mu \mathrm{g} \mathrm{ml}^{-1}$ final concentration and the precipitate was removed by centrifugation at $12000 \mathrm{~g}$ for $30 \mathrm{~min}$. The supernatant was dialysed against phosphate buffer $(25 \mathrm{mM}, \mathrm{pH} 6.5)$ and purified in the same way as the extracellular enzyme but the AcA 44 chromatography step was omitted. The purified enzyme migrated as a single band after SDS-PAGE.

Molecular weight determination. The molecular weights of the purified $\alpha$-glucosidases were determined by SDSPAGE using ( $M_{\mathrm{r}}$ in parentheses) bovine serum albumin (66000), pyruvate kinase $(57000)$, lactate dehydrogenase (36000), lysozyme (14300) and RNAase (13700) for calibration. 
Effects of temperature and $\mathrm{pH}$ on the activity and stability of $\alpha$-glucosidase. The effect of temperature on enzyme activity was determined by doing the standard enzyme assay at a range of temperatures between 20 and $60^{\circ} \mathrm{C}$, with $5{ }^{\circ} \mathrm{C}$ increments, using $0.1 \mathrm{ml}$ of the purified enzymes adjusted to 5 units $\mathrm{ml}^{-1}$ at $37^{\circ} \mathrm{C}(100 \%$ activity). The effect of temperature on enzyme stability was examined by incubating the purified enzymes ( $1 \mathrm{ml}$ of 100 units $\left.\mathrm{ml}^{-1}\right)$ in phosphate buffer $\left(0 \cdot 1 \mathrm{M}, \mathrm{pH} \mathrm{6.5)}\right.$ at $20,37,45,50$ and $60^{\circ} \mathrm{C}$. After $60 \mathrm{~min}, 0 \cdot 1 \mathrm{ml}$ of the enzyme was removed and the residual activity was assayed at $37^{\circ} \mathrm{C}$. The effect of $\mathrm{pH}$ on enzyme activity was examined using citrate/phosphate ( $\mathrm{pH} 3$ to 5.5 ), sodium phosphate ( $\mathrm{pH} 5.5$ to 8.0 ) and glycine/ $\mathrm{NaOH}$ (pH 8 to 10 ) buffers, all at $0 \cdot 1 \mathrm{M}$, in place of the phosphate buffer in the standard assay mixture. Enzyme assays using 5 units purified enzyme $\mathrm{ml}^{-1}$ were done at $\mathrm{pH} 3$ to 10 using the appropriate blanks. To assess the effect of $\mathrm{pH}$ on enzyme stability, 20 units of enzyme were adjusted to $2 \mathrm{ml}$ with the buffers used above and incubated for $20 \mathrm{~min}$ and for $24 \mathrm{~h}$. The enzyme buffer solutions were assayed for residual activity at $\mathrm{pH} 6.5$.

\section{RESULTS}

\section{Purification of $\alpha$-glucosidases}

Summaries of the purification of the intracellular and extracellular $\alpha$-glucosidases of Bacillus licheniformis NCIB 6346 are given in Table 1. The specific activities of the purified enzymes were 1017 and 960 units (mg protein) ${ }^{-1}$ for the extracellular and intracellular enzymes respectively. The purified enzymes ( $50 \mu \mathrm{g}$ protein) migrated as single bands in SDS-PAGE. The subunit molecular weights of both enzymes were 63000 and, when electrophoresed together, they migrated as a single molecular species.

\section{Characteristics of the purified enzymes}

The two enzymes behaved almost identically with respect to temperature and $\mathrm{pH}$ (Figs 1 and 2). At $50{ }^{\circ} \mathrm{C}$, enzyme activity was almost twice that at $37^{\circ} \mathrm{C}$ but above this temperature it declined rapidly. At $55^{\circ} \mathrm{C}$ activity was $65 \%$ of the $37^{\circ} \mathrm{C}$ figure and at $60^{\circ} \mathrm{C}$ activity was virtually undetectable. Similarly, the enzymes lost activity when incubated at elevated temperatures. The enzymes were stable without loss of activity for $60 \mathrm{~min}$ at 20 and $37^{\circ} \mathrm{C}$ but at $50{ }^{\circ} \mathrm{C}, 40 \%$ of their activity was lost during this period. All activity was lost in $10 \mathrm{~min}$ at $60^{\circ} \mathrm{C}$.

The optimum $\mathrm{pH}$ for enzyme activity was around 6.0 , although $90 \%$ activity was obtained at $\mathrm{pH} 7.0$ (Fig. 2). Below pH 4.5 and above $\mathrm{pH} 9.5$ there was no activity. The enzymes displayed a

\section{Table 1. Summary of purification of $\alpha$-glucosidases}

\begin{tabular}{|c|c|c|c|c|c|}
\hline Source & Fraction & $\begin{array}{l}\text { Total enzyme } \\
\text { activity } \\
\text { (units) }\end{array}$ & $\begin{array}{l}\text { Total protein } \\
\text { (mg) }\end{array}$ & $\begin{array}{c}\text { Specific activity } \\
\text { [units (mg protein })^{-1} \text { ] }\end{array}$ & $\begin{array}{c}\text { Yield } \\
\left(\begin{array}{c}0 \\
\%\end{array}\right)\end{array}$ \\
\hline \multirow[t]{8}{*}{ Extracellular } & Supernatant & 21045 & 28578 & 0.736 & 100 \\
\hline & $\begin{array}{l}\text { Ammonium sulphate } \\
\text { precipitation }\end{array}$ & 18600 & 3131 & 5.94 & 88 \\
\hline & $\begin{array}{l}\text { DEAE-cellulose } \\
\text { chromatography }\end{array}$ & 13320 & 360 & $37 \cdot 0$ & 63 \\
\hline & $\begin{array}{l}\text { Ammonium sulphate } \\
\text { precipitation }\end{array}$ & 8816 & 117 & 75.5 & 42 \\
\hline & Sephadex G-200 & & & & \\
\hline & gel filtration & 8305 & 40 & $208 \cdot 1$ & 39 \\
\hline & $\begin{array}{l}\text { Ultragel AcA } 44 \text { gel } \\
\text { filtration }\end{array}$ & 7917 & $9 \cdot 6$ & 821 & 38 \\
\hline & Preparative PAGE & 4908 & 4.8 & 1017 & 23 \\
\hline \multirow[t]{6}{*}{ Intracellular } & Lysed cells & 54400 & 1350 & $40 \cdot 3$ & 100 \\
\hline & $\begin{array}{l}\text { Ammonium sulphate } \\
\text { precipitation }\end{array}$ & 52500 & 684 & $76 \cdot 7$ & 96 \\
\hline & $\begin{array}{l}\text { DEAE-cellulose } \\
\text { chromatography }\end{array}$ & 18480 & $90 \cdot 3$ & 204 & 33 \\
\hline & $\begin{array}{l}\text { Ammonium sulphate } \\
\text { precipitation }\end{array}$ & 15900 & $39 \cdot 7$ & 399 & 29 \\
\hline & $\begin{array}{l}\text { Sephadex G-200 } \\
\text { gel filtration }\end{array}$ & 9628 & $22 \cdot 3$ & 431 & 18 \\
\hline & Preparative PAGE & 5392 & $5 \cdot 6$ & 960 & 10 \\
\hline
\end{tabular}




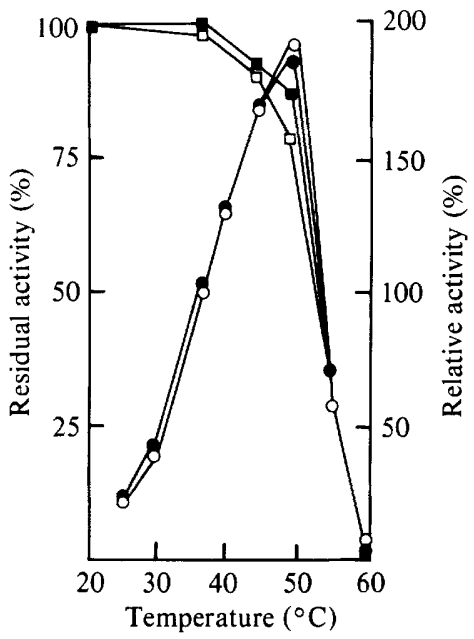

Fig. 1

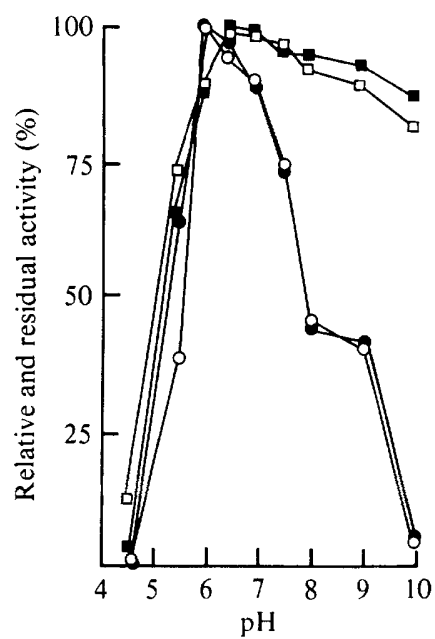

Fig. 2

Fig. 1. Effect of temperature on the activity (circles) and stability (squares) of the intracellular (open symbols) and extracellular (filled symbols) $\alpha$-glucosidases.

Fig. 2. Effect of $\mathrm{pH}$ on the activity (circles) and stability (squares) of the intracellular (open symbols) and extracellular (filled symbols) $\alpha$-glucosidases.

\section{Table 2. Substrate specificities of $\alpha$-glucosidases from Bacillus licheniformis}

Substrates were incubated with purified enzyme $\left(100\right.$ units $\left.\mathrm{ml}^{-1}\right)$ for $30 \mathrm{~min}$ at $37^{\circ} \mathrm{C}$ and the glucose released was assayed and compared to that released from $p$-nitrophenyl $\alpha$-D-glucopyranoside (PNPG). There was no detectable activity with amylose $(1 \%, w / v)$, amylopectin $(1 \%, w / v)$, cellobiose, lactose, melibiose, methyl $\alpha$-D-glucopyranoside, $p$-nitrophenyl $\beta$-D-glucopyranoside, raffinose, salicin or trehalose (all at $1 \mathrm{~mm}$ ) as substrate.

Substrate (1 mM)

$p$-Nitrophenyl $\alpha$-D-glucopyranoside
Isomaltose
Maltotriose
Sucrose
Maltose
Phenyl $\alpha$-D-glucopyranoside

Relative hydrolysis rate $(\%)$

Extracellular enzyme Intracellular enzyme

$\begin{array}{rr}100 & 100 \\ 226 & 219 \\ 142 & 156 \\ 56 & 51 \\ 55 & 49 \\ 20 & 21\end{array}$

wide range of $\mathrm{pH}$ stability. More than $80 \%$ residual activity was obtained between $\mathrm{pH} 5.5$ and $\mathrm{pH} 10 \cdot 0$. The enzymes were unstable below pH $5 \cdot 0$ even when incubated for only $20 \mathrm{~min}$.

The substrate specificities of the enzymes are shown in Table 2. Of the substrates examined, maximal activity occurred with isomaltose followed by maltotriose, PNPG, sucrose, maltose and phenyl $\alpha$-D-glucopyranoside. The enzymes did not hydrolyse polysaccharides such as amylose, amylopectin or glycogen. They were inhibited by glucose, glucono- $\delta$-lactone and Tris, and to a lesser extent by erythritol, xylose and inositol. They were not affected by EDTA (Table 3).

The products of hydrolysis of maltose, isomaltose and maltotriose by the purified extracellular and lysozyme-released enzymes were essentially the same. Maltose was slowly hydrolysed to glucose. Maltotriose was hydrolysed more rapidly to yield maltose and glucose, and the maltose produced was slowly hydrolysed to glucose. However, isomaltose was rapidly hydrolysed to glucose. In both the isomaltose and maltotriose reactions there was evidence of transglucosylase activity (Fig. 3). 


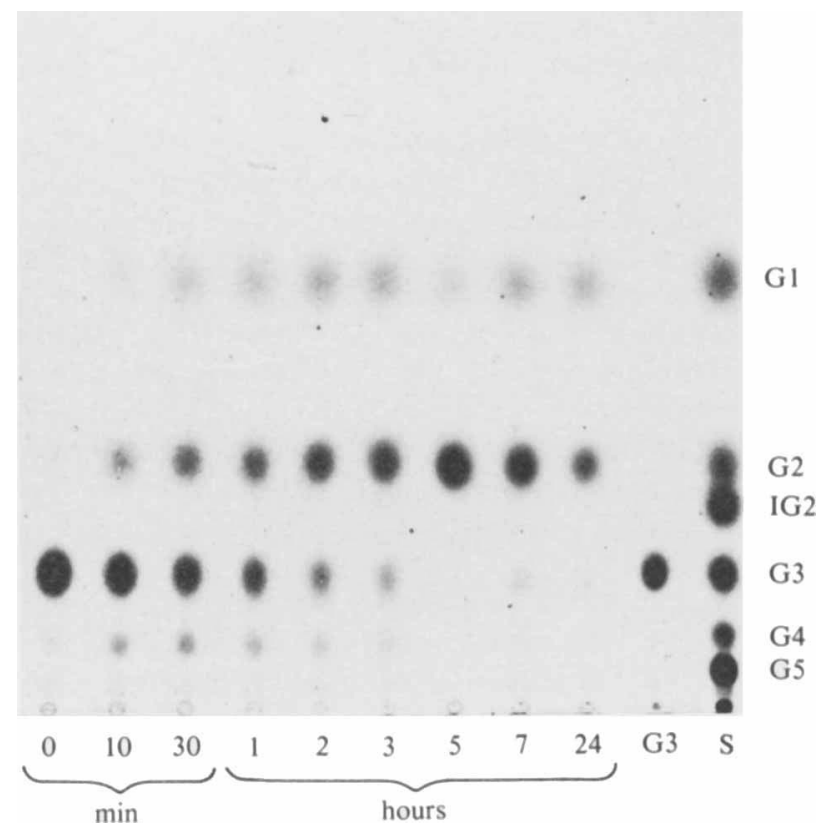

Fig. 3. Thin layer chromatographic analysis of the action of the purified extracellular $\alpha$-glucosidase (100 units in $1.5 \mathrm{ml} \mathrm{0.1} \mathrm{M-phosphate} \mathrm{buffer,} \mathrm{pH} \mathrm{6.5)} \mathrm{on} \mathrm{maltotriose}\left(2.5 \mathrm{mg} \mathrm{ml}^{-1}\right)$. Samples $(15 \mu \mathrm{l})$ were analysed at the times shown. GX, oligosaccharides with X maltose units. IG2, isomaltose; $\mathrm{S}$, standard reference mixture comprising a partial acid hydrolysis of starch that has been checked against authentic standards.

Table 3. Inhibitory effects of various compounds on the activity of $\alpha$-glucosidases from Bacillus licheniformis

Purified enzyme ( 12.5 units $\left.\mathrm{ml}^{-1}\right)$ was incubated with inhibitor for $20 \mathrm{~min}$ at $20^{\circ} \mathrm{C}$ and the residual activity was assayed and compared to enzyme in phosphate buffer $(0 \cdot 1 \mathrm{M}, \mathrm{pH} 6.5)$. Galactose, EDTA, fructose, methyl $\alpha$-D-glucopyranoside and sorbitol at $5 \mathrm{mM}$ (25 mM for EDTA) had no effect on enzyme activity.

\begin{tabular}{lccc}
\multirow{2}{*}{$\begin{array}{l}\text { Inhibitor } \\
\text { Erythritol }\end{array}$} & $\begin{array}{c}\text { Concn } \\
(\mathrm{mM})\end{array}$ & $\overbrace{\text { Extracellular enzyme }}$ & Relative activity (\%) \\
Glucose & 1 & 98 & 100 \\
& 5 & 81 & 79 \\
Glucono- $\delta$-lactone & 1 & 44 & 43 \\
Inositol & 5 & 13 & 19 \\
& 1 & 44 & 50 \\
Tris & 5 & 23 & 19 \\
& 1 & 88 & 92 \\
Xylose & 5 & 77 & 76 \\
& 1 & 21 & 1 \\
& 5 & 3 & 100 \\
& 1 & 100 & 79
\end{tabular}

\section{DISCUSSION}

Purification and characterization of an intracellular and an extracellular $\alpha$-glucosidase from $B$. licheniformis NCIB 6346 has revealed that both enzymes show virtually identical properties. Like the $\alpha$-glucosidase of $B$. cereus (Yamasaki \& Suzuki, 1974), B. subtilis (Wang \& Hartman, 1976) and B. brevis (McWethy \& Hartman, 1979) they showed maximal activity at about $50^{\circ} \mathrm{C}$. 
The $\mathrm{pH}$ optima for activity of both $\alpha$-glucosidases from $B$. licheniformis were about $\mathrm{pH} 6 \cdot 0$, similar to the $\mathrm{pH}$ optima for $\alpha$-glucosidases from other Bacillus strains and yeasts (Kelly \& Fogarty, 1983).

The two $\alpha$-glucosidases from $B$. licheniformis NCIB 6346 had the same specificity for the substrates examined. The enzymes behaved more like an isomaltase than maltase since they had a higher specific activity towards isomaltose than maltose. This is unusual, since a recent analysis of the substrate specificities of 12 bacterial $\alpha$-glucosidases showed 10 to have highest activity towards maltose and of these only three showed positive activity towards $(1 \rightarrow 6)-\alpha$-glucosides (Kelly \& Fogarty, 1983). The two remaining enzymes (from ' $B$. amyloliquefaciens' and an unidentified Bacillus strain) showed highest activity toward sucrose and PNPG respectively. The former also possessed activity on PNPG and isomaltose (Urlaub \& Wöber, 1978) and therefore is the most similar to the enzymes from $B$. licheniformis. Several $\alpha$-glucosidases possess transglucosylation activity and generally synthesize $(1 \rightarrow 6)-\alpha$-linked oligosaccharides (Kelly \& Fogarty, 1983 ). The enzymes from $B$. licheniformis showed transglucosylation activity when maltotriose or isomaltose was supplied as substrate.

$\alpha$-Glucosidase, like the peripheral, membrane-associated alkaline phosphatase of $B$. licheniformis, can be removed by washing cells with $\mathrm{NaCl}$ or Triton (Spencer et al., 1981; Kumar et al., 1983; Thirunavukkarasu \& Priest, 1983). This suggests a membrane-associated location for $\alpha$-glucosidase, but all attempts to recover $\alpha$-glucosidase activity from membranes have failed (G. Gammack \& F. G. Priest, unpublished information). In common with alkaline phosphatase (Glynn et al., 1977; Spencer et al., 1982), the intracellular and extracellular $\alpha$-glucosidases have essentially the same subunit molecular weights and could not be resolved by SDS-PAGE. This eliminates the involvement of a hydrophobic sequence containing a lipid moiety in the localization of these enzymes, as found in the membrane-bound penicillinase of this bacterium (Nielsen et al., 1981). Thus, if the cellular location of $\alpha$-glucosidase is largely associated with the membrane, as suggested by in vitro translation studies (Thirunavukkarasu \& Priest, 1983), the localization process seems to resemble the alkaline phosphatase rather than the penicillinase of this organism.

\section{REFERENCES}

GlynN, J. A., Schafeli, S. D., MCNicholas, J. M. \& HuLETT, F. M. (1977). Biochemical localization of the alkaline phosphatase of Bacillus licheniformis as a function of culture age. Journal of Bacteriology 129, 1010-1019.

KeLly, C. T. \& FogarTy, W. M. (1983). Microbial $\alpha-$ glucosidases. Process Biochemistry 18, 6-12.

Kelly, C. T., HefFernan, M. E. \& Fogarty, W. M. (1980). A novel $\alpha$-glucosidase produced by Bacillus amylolyticus. Biotechnology Letters 2, 351-356.

Kumar, R., Ghosh, A. \& GHosh, B. J. (1983). Alkaline phosphatase secretion-negative mutant of Bacillus licheniformis 749/C. Journal of Bacteriology 154, 946954.

McWethy, S. J. \& HaRtman, P. A. (1979). Extracellular maltase of Bacillus brevis. Applied and Environmental Microbiology 37, 1096-1102.

Nielsen, J. B. K., Caulfield, M. P. \& Lampen, J. O. (1981). Lipoprotein nature of Bacillus licheniformis membrane penicillinase. Proceedings of the National Academy of Sciences of the United States of America 78, 3511-3515.

Spencer, D. B., Chen, C.-P. \& Hulet, F. M. (1981). Effect of cobalt on synthesis and activation of Bacillus licheniformis alkaline phosphatase. Journal of Bacteriology 145, 934-945.

SPENCER, D. B., HANSA, J. G., StuckmanN, K. V. \& HuLeT, F. M. (1982). Membrane-associated alkaline phosphatase from Bacillus licheniformis that requires detergent for solubilization: lactoperoxidase ${ }^{125} \mathrm{I}$ localization and molecular weight determination. Journal of Bacteriology 150, 826-834.

Suzuki, A. \& TANakA, R. (1981). Production of $p$-nitrophenyl- $\alpha$-D-glucopyranoside hydrolysing $\alpha$-glucosidase by Bacillus cereus ATCC 7064. European Journal of Applied Microbiology and Biotechnology 11, 161-165.

Suzuki, Z., Kishigami, T. \& ABE, S. (1976a). Production of extracellular $\alpha$-glucosidase by thermophilic Bacillus species. Applied and Environmental Microbiology 31, 807-812.

SuzUKI, Z., TsujI, T. \& ABE, S. (1976b). Production of an extracellular maltase by a thermophilic Bacillus sp. KP1035. Applied and Environmental Microbiology 32, 747-752.

Suzuki, Y., Ueda, Y., Nakamura, N. \& Abe, S. (1979). Hydrolysis of low molecular weight isomaltosaccharides by a $p$-nitrophenyl- $\alpha$-D-glucopyranosidehydrolyzing $\alpha$-glucosidase from a thermophile, Bacillus thermoglucosidius KP1006. Biochimica et biophysica acta 566, 62-66.

Thirunavukkarasu, M. \& Priest, F. G. (1983). Synthesis of $\alpha$-amylase and $\alpha$-glucosidase by membrane-bound ribosomes from Bacillus licheniformis. Biochemical and Biophysical Research Communications 114, 677-683.

URLAUB, H. \& WöBER, G. (1978). $\alpha$-Glucosidase, a membrane-bound enzyme of $\alpha$-glucan metabolism in 
Bacillus amyloliquefaciens: purification and partial characterization. Biochimica et biophysica acta $\mathbf{5 2 2}$, 161-173.

Wang, L. H. \& Hartman, P. A. (1976). Purification and some properties of an extracellular maltase from Bacillus subtilis. Applied and Environmental Microbiology 31, 108-118.
WEBER, K. \& OsBORN, M. (1969). The reliability of molecular weight determination by dodecyl sulfate polyacrylamide gel electrophoresis. Journal of Biological Chemistry 244, 4406-4412.

YAMASAKI, Y. \& SuzuKI, Y. (1974). Purification and properties of $\alpha$-glucosidase from Bacillus cereus. Agricultural and Biological Chemistry 38, 443-454. 